\title{
SALT can have too high a price
}

WITH the last details settled in the second round of Strategic Arms Limitation Talks (SALT-2), a treaty which has been under negotiation for more than four years is closer to reality. The agreement will be signed by the heads of state of the two superpowers in a month's time, but on the United States' side there will still remain one major hurdleratification by the US Senate with at least 67 of 100 votes in favour. And there are all manner of reasons why 34 senators could be persuaded to vote against ratification.

The fundamental principles of the treaty have been wellknown for some time. Each side's 'strategic' launchers will be limited in number to 2,250 . This figure is slightly higher than the present US total of launchers, including intercontinental ballistic missiles (ICBMs), heavy bombers and submarine missile tubes. It is 250 lower than the Soviet total, so there will have to be some dismantling on the Soviet side. There will be no specific restriction on the weight these launchers may carry, but not more than 820 ICBMs may be fitted with multiple independently targetable re-entry vehicles. In a first grapple with the problem of low altitude cruise missiles their range will be restricted to 600 kilometres.

Rhetcric on the need for SALT 2 is predictably hotting up. At various times President Carter has claimed that it will "make the world safer and more secure", that ratification will be "the most important single achievement that could possibly take place for our our nation during my [Carter's] lifetime" and that failure to ratify would release nuclear weapons constraints on countries such as Pakistan, India, South Korea, Taiwan and South Africa. But despite these questionable assertions and despite an apparent general support for SALT-2 in the US, there are still identifiable groups opposed to ratification.

There are, not surprisingly, those whose political complexion does not predispose them to favour any deal at all with the Soviet Union. Then there are those who would only favour a deal with the Soviet Union if it were coupled with other issues such as human rights and military constraints elsewhere (such as Africa). Further, some, not in principle opposed to arms-control agreements, will find SALT-2 in one way or another not an adequate measure. And there will be those who have great concern that the
US procedures for verification, despite firm assertions to the contrary, do not guarantee that the Soviet Union cannot cheat without certainty of detection.

There is, however, another position from which one can have the deepest concern about SALT-2 whilst holding the most impeccable credentials in favour of arms control. It runs as follows.

In the process of 'selling' SALT-2 to Senate, President Carter is going to have to reassure many of the waverers that he is not dismantling US strength in the strategic field. He has already said that the treaty will allow the US to pursue "all the defence programmes we believe we may eventually need", and this list is formidable. At the top of it undoubtedly come a new mobile missile (the MX) and the Trident submarine with its associated missiles. But there are also new air-, ground- and sealaunched missiles, a new bomber, and aircraft to carry cruise missiles. This year's defence budget also shows that there will be more spent on basic and applied research; favoured areas in future will be space (particularly the Shuttle), lasers and anti-satellite measures. The phrase of the particle physicists "all that isn't forbidden is compulsory" is easily transferred to the world of military procurement.

It does seem that the price that will be exacted for SALT-2 is going to be commitment to a disturbingly wide range of new military programmes. Those with long memories will recall that in 1963 a somewhat similar situation arose when the price for the Partial Test Ban was a commitment by President Kennedy to vigorous underground weapons testing, which effectively degraded an arms control measure into an anti pollution measure.

Some thoughtful people will wonder whether this sort of game is worth the candle. If the only way to achieve arms control is to turn up the volume elsewhere, isn't it time to stop deluding ourselves that the SALT agreements are so valuable? On balance such sentiments should not lead to a vote against ratification, because if ratification fails the forces of aggressive military procurement succeed even more strongly. But there certainly should be pause for thought, and SALT-3, bringing in European nations, should not be yet another occasion for simultaneously slowing and speeding up the arms race. 